\title{
A nonlinear simultaneous equation analysis of managerial ownership and debt policy: Evidence from Tunisian Stock Exchange
}

Fatma Ben Moussa (Corresponding author)

University of Tunis El Manar,

Faculty of Economic Sciences and Management of Tunis, Tunisia

E-mail: bmoussa_fatma@yahoo.ca

Jameleddine Chichti

Jameleddine Chichti : Business School of Tunis (ESCT), Manouba University, B.P. 2010,

Manouba, Tunisia

Received: November 28, 2013 Accepted: December 12, 2013 DOI: 10.5296/ijafr.v3i2.4637

\begin{abstract}
The agency relationship between managers and shareholders has the potential to influence decision-making in the firm which in turn potentially impacts on firm characteristics such as leverage. Prior evidence has demonstrated an association between ownership structure and firm value. This paper extends the literature by examining a further link between ownership structure and capital structure. Based on a system of simultaneous equations on the basis of a panel of Tunisian companies listed on the Tunisian stock exchange during the period 2000-2009, our results show that the ownership structure affects the capital structure and vice versa. In addition, the relationship between debt and managerial ownership is nonlinear.
\end{abstract}

Keywords: Corporate governance, debt policy, ownership structure, free cash flow 


\section{Introduction}

Questions regarding the interface between corporate finance and corporate governance have, gained prominence in recent years. Several previous studies have examined the effects of capital structure on firm performance regardless of the ownership structure (Titman and Wessels 1988). However, others have evaluated the effects of ownership structure on firm performance regardless of the capital structure (Mester 1993, Pi and Timme, 1993, Gorton and Rosen, 1995, DeYoung, Spong and Sullivan 2001). Finally, other research includes two variables but consider debt as an exogenous variable, rather than a structure of simultaneous equations (Mehran 1995, McConnell and Servaes 1995). Nevertheless, few studies have attempted to examine the effect of corporate governance, in particular the structure of ownership and control over the debt policy.

Berger et al (2006) suggest that the ownership structure and capital structure should be included in studies of agency costs, since it is the separation of ownership and control that create costs agency. As the capital structure is related to agency and agency costs, in turn is associated with shareholder rights, the authors assume that the financial decisions are influenced by the level of ownership of the various shareholders within the firm.

Friedman, Johnson and Mitton (2003) estimate the relationship between corporate governance and the level of debt for a sample of 447 Asian, European and Latin American firms. They find, for Asian firms, a result that low corporate governance is associated with high levels of debt.

Recently, Bunkanwanichay, Guptaz and Rokhimx (2008) studied the relationship between corporate governance and debt structure from a sample of 500 listed companies in Thailand and Indonesia. The empirical results show that firms with low governance system tend to borrow more. In addition, the results confirm the idea that debt can facilitate the entrenchment especially in firms where the governance system is ineffective.

The relationship between managerial ownership and debt policy has been the subject of much controversy in the literature on governance. Jensen and Meckling (1976) indicated that the decision of the managers on the capital structure results from a trade-off between the agency costs of debt and equity reducing their impact on the value of the company. The managers agreed to bear the costs of equity financing in the event that their investment provides significant results allowing them to offset the costs. Otherwise, managers return to their creditors to finance growth projects.

Note that the studies on the relationship between managerial ownership and debt lead to different conclusions. On the one hand, some studies lead to a positive relationship that the managers back into debt to not dilute the ownership and therefore increase their voting power. On the other hand, empirical studies confirm that managerial ownership negatively affects the debt level of firms. Indeed, when managers hold a significant percentage of the capital, they undergo a significant non- diversifiable risk and should reduce the level of debt in order to limit the risk of bankruptcy.

Finally, conflicting results oriented research to the study of a possible non-linear relationship 
between ownership structure and debt policy.

\section{Literature Review and research hypotheses}

\subsection{Managerial ownership and debt policy}

\section{Positive relationship between debt and managerial ownership}

Stulz (1988) indicates that the debt policy can be presented as an instrument of discretionary management of managers and not a control mechanism. Indeed, using the debt managers can neutralize constraint after an attempted takeover bid.

Also, Novaes and Zingales (1995) and Zwiebel (1996) show that the choice of using the debt differs from the point of view of the manager and the shareholder. The authors support the idea of using mangers in debt. Indeed, the threat of takeover lead managers to issue debt as proof of their alignment. They reject negative NPV projects because debt increases the risk of failure due to overinvestment. Managers increase the use of debt for several reasons: first, maximize the firm value: in fact, by studying the role of debt in the context of a potential agency conflict between internal and external, Grullon et al (2001) examine whether debt levels are chosen in order to eliminate the conflict or to allow entrenchment. They argue that the massive use of debt can control the behavior of managers (disciplinary role of debt). Second, consolidate their voting power (Harris and Raviv, 1988) and in this case, managers are forcing potential buyers to pay a higher premium for corporate control and thirdly to establish a defensive restructuring (Stiglitz, 1988). To this end, Berger et al (1997) found that firms are more indebted, when there are changes that could threaten the safety of managers, such as the attempt acquisition of the firm, the forced resignation of the managers and the emergence of large shareholders as directors.

Moreover, Prasard et al (2001) describe three arguments in favor of a positive relationship between managerial ownership and debt levels: first, firms with high managerial participation face significant agency costs of issuance of shares. Second, firms with high managerial participation face low costs of debt (convergence of interests between shareholders and managers). Finally, managers of firms with high managerial participation may issue more debt with the aim of consolidate their voting rights.

The author reiterates that managers, setting investment projects by issuing debt can maintain a certain level of voting without even investing in the firm. The author indicates that a very high debt ratio could discourage investors. Therefore, the financing of investment projects by debt rather than by issuing new shares, consolidates control of the current managers, thereby serving as a strategy of resistance against the takeover.

Chen (2006) reports a negative association between managerial ownership and firm valuation at low levels of managerial ownership. Borrowing from these findings, it seems likely that managerial ownership, debt and firm valuation are jointly determined.

Al- Deehani and Al- Saad (2006) studied the relationship between ownership structure and capital structure of companies listed on the Kuwait Stock Exchange. Their empirical study shows a positive relationship between the amount of the debt and the amount of control 


\section{Mll Macrothink}

International Journal of Accounting and Financial Reporting ISSN 2162-3082 2013, Vol. 3, No. 2

related to the amount of cash flow rights. Also, they show a positive relationship between the amount of debt and managerial ownership. Other positive relationships were also shown between the amount of debt, the amount of control rights and rights to free cash flow and the concentration of ownership in the hands of a family.

Recently, Godfred et al. (2009) examining the effect of ownership structure and corporate governance of the financing decision based on a sample of companies listed on the Ghana Stock Exchange for the period 2002 -2007 . The empirical results show that managerial ownership is positively related to the long-term debt level. Also, the debt policy is affected by the tangibility, earnings volatility, profitability and the dividend policy.

Finally, it can be seen from these studies, a positive relationship between managerial ownership and debt policy is based on two theories that are the theory of convergence of interests and thesis of entrenchment through the concentration of voting rights.

\section{Negative relationship between debt and managerial ownership}

The arguments can be advanced to explain the existence of a negative relationship between the level of debt and the property managers are three. First, managers are very risk averse and thus they avoid debt for fear of driving the company into a bankruptcy situation (Short and Keasey, 1999). Second, optimism managers could explain the negative impact of managerial ownership on the level of debt. Thus, Heaton (1998) states, that the optimism of managers could explain the use of a pecking order. Optimistic managers consider the capital market undervalues the risks associated with the securities of the company. This implies a preference for internal financing and safely. These preferences may have costs. Indeed, in the absence of internal funds, optimistic managers abandon profitable projects. However, such decisions may prevent the firm to other costs, such as investment in unprofitable projects. Optimism leads in some cases to reduce the use of debt as a means of financing (Noe and Rebello, 1996). Third, the negative relationship between managerial ownership and debt may be due to the entrenchment. Generally, the interest of managers differed from those of a minority shareholder. Indeed, the managers run the risk of employment and the risk of non- diversified portfolio. Also, the managerial ownership supports the development of defensive strategies of capital - increase in debt - due to the strengthening of the power within the firm, but also the motivation to maintain control. So the managerial ownership is a way facilitating entrenchment.

In the context of trade-off between debt and managerial ownership, several research (Bathala et al, 1994; Crutchley and Hansen, 1989; Freind and Hasbrouck, 1987 Freind and Lang, 1988), suggest that the debt can substitute for managerial ownership in reducing agency costs. In fact, at high marginal tax rates, the cost of debt decreased due to the reduction of debt and increased managerial ownership.

Several recent empirical studies have investigated the relationship between managerial ownership and debt while highlighting the entrenchment (Grullon et al, 2001; Wu, 2004, Lee and Yeo, 2007; Ghosh, 2007; Abor, 2008 Safdar and Arshad, 2009; Litov, 2005).

Finally, it should be noted that studies on the relationship between managerial ownership and 
debt lead to different conclusions. These conflicting results oriented research to the study of non-linear relationship between ownership and debt (Dutta, Collins and Wansley, 2000, Brailsford et al, 2002; Bruslerie Of 2004; Kumar, 2004 Ruan et al (2009) ... etc). . . According to the authors, the studies cited do not allow to reveal decisive and concurrent results, and possibly because of the different test methods used. This may still be due to the measure chosen level of debt (total debt, long-term or short-term, accounting measures or market ...). Another possible interpretation is that the choice of a linear relationship is wrong from the beginning and that researchers would have considered that the relationship between managerial ownership and debt is rather non-linear.

\section{Debt and managerial ownership: a non-linear relationship}

To overcome the shortcomings of the studies cited above, several studies have tested the curvilinear relationship between debt and managerial ownership. Thus, based on a system with simultaneous equations, Dutta, Collins and Wansley (2000) examine the nonlinear effect of the managerial ownership on debt and dividend policies. The empirical results show that the thresholds of $5 \%$ and $25 \%$ of managerial ownership confirming the existence of a nonlinear relationship. According to the authors, low levels of managerial ownership are significantly related to high levels of debt while firms with managerial ownership between $5 \%$ and $25 \%$ use less debt.

Focusing on Australian firms, Brailsford, Oliver and Pua (2002) indicate that, for low levels of managerial ownership, managerial participation is positively related to the debt to align the interests of managers with those of shareholders. However, at high levels of managerial ownership, they become more entrenched and trying to reduce their risk and therefore the debt is limited. The authors propose an empirical model showing the non-linear relationship and an inflection point which is at 33\% of managerial ownership. The same result was shown by Berger et al. (1997) and Kumar (2004).

Recently, Ruan et al. (2009) indicate that at low levels of managerial ownership, managers have a limited power to vote, however external shareholders, such as block holders and creditors, have the ability to control and restrict the opportunistic behavior of managers. The managerial ownership and debt will in this case two substitutable governance mechanisms. However, when managers hold a significant percentage of capital, external shareholders have no power over the managers, who use debt as a entrenchment tool to escape from a hostile takeover. In this case the level of debt is positively related to managerial ownership. Finally, when managerial ownerial is very high; managers have absolute control of the firm. In this case, they prefer to reduce the level of debt to reduce their exposure to risk.

To summarize, we can say that the positive relationship between managerial ownership and debt levels may be due to an effect of convergence of interest or to an entrenchment effect via the concentration of voting rights. However, the negative relationship between managerial participation and the ratio of debt is due to the fact that managers are risk averse of bankruptcy threatening their jobs and wealth invested in the company.

Recently, more studies testing the hypothesis of the existence of a nonlinear relationship 


\section{Ml Macrothink}

International Journal of Accounting and Financial Reporting ISSN 2162-3082 2013, Vol. 3, No. 2

between managerial ownership and debt. In general, these studies reach similar to those found in the context of the relationship between managerial ownership and the value or performance of the company. Thus, an alignment effect is associated with low or very high levels of managerial ownership levels, entrenchment effect is triggered from a certain point of the ownership providing a manager a power pushing him to lower the debt and for weakening its risk without having to change its wealth invested in the company, probably due to the consumption of private benefits offsetting the decline in the value of the firm due to lower level of debt ratio.

\section{Impact of debt policy on managerial ownership}

Some studies show that the distribution of share ownership may be influenced by the capital structure (Huson et al. 2006; De La Bruslerie and Latrous, 2007; Ruan, Tian and Ma, 2009). These studies are based on the fact that the interaction between ownership structure and capital structure is not taken into account can lead to simultaneity bias. To eliminate this bias, the authors adopt the methodology of simultaneous equations.

Agrawal and Mandelker (1987) test the relationship between managerial ownership and financing policy of the firm. The authors find that the holding of securities by managers of firms whose debt ratio increases is more pronounced than those firms whose ratio decreases. Thus, when making financing decisions, managerial ownership can reduce agency conflicts by pushing managers to forgo opportunistic behavior may adversely affect the level of debt.

The authors report a reduction in the level of debt could have three potential effects on managerial wealth. First, a reduction in the ratio of «debt / equity» (caused, for example, by an additional issue of shares made by an acquiring firm to finance a merger by exchange of shares) reduces the probability of failure of the firm. As future revenues of managers are related to the continuity of the firm, debt reduction increases the value of their human capital.

The same thing is for the current value of risky debt. If the financing decision has no effect on the total value of the firm, the value of existing shares and options on those shares is reduced. Therefore, the value of shares and options of managers decreases. Finally, a reduction in the level of debt also reduces the variance of stock returns, implying a change in the variance of the total wealth portfolio managers. Therefore, the presence of debt in the capital structure of the firm increases its risk and discourages risk-adverse managers to hold more equity in them.

Using 100 Composite Index companies from Brusa Malaysia from 1998 to 2002, Huson et al. (2006) studied the relationship between managerial ownership and debt of firm by using a simultaneous equations estimation procedure (2SLS). The findings show that there is a significant impact of institutional ownership which serves effective control mechanism on managerial ownership and corporate debt policy. Findings of such evidence suggest that institutional holding thus have played an important role in managers' strategic management decision and reduce agency conflict. Additionally, the study finds that the debt ratio is inversely related to managerial equity ownership and $R \& D$ expenses. The negative coefficient for managerial ownership in the debt equation supports the notion that these two 
variables monitoring substitutes in the agency framework.

La Bruslerie and Latrous (2007) studied the relationship between ownership structure and debt of firm listed on the Paris stock exchange over the period from 1998 to 2002. Specifically, the authors tested the nonlinear effect of controlling shareholders ownership on the debt level as well as the interaction between capital structure and ownership structure. By using a simultaneous equations estimation procedure (3SLS), empirical results show that the debt increases and then decreases with the percentage of shares held by the controlling shareholders with an inflection point equal to $40 \%$. In addition, the results confirmed the existence of a significant interaction between ownership structure and capital structure. Thus, controlling shareholders ownership affects the financial structure and vice versa. The results indicate that the various measures of the debt ratio affect negatively and significantly the controlling shareholders ownership. This result suggests that they decide to reduce their equity when the debt measured at book value and market value ratio increases.

Ruan, Tian et Ma (2009) extend the previous research (Cho 1998; Davies et al. 2005; Morck et al. 1988and Short \& Keasey 1999) in at least two respects. First, they introduced capital structure as an intermediate variable between managerial ownership and corporate value. By using simultaneous equations, they detected the interrelationship between managerial ownership, firm value and capital structure and found the intermediate role of capital structure. Second, they extended the research from developed markets to the emerging Chinese market - a necessary development from previous studies. Through examination of a sample of 197 civilian-run listed firms between 2002 and 2007, the authors found a nonlinear relationship between Tobin's Q and the fraction of shares owned by boards of directors which is consistent with the results of Cho (1998), Miguel et al. (2004) Morck et al. (1988) and Short and Keasey (1999). Tobin's Q, which is a proxy of firm performance, increases as managerial ownership grows until it reaches 18 per cent. Thereafter, Tobin's Q declines with the increase in managerial ownership until it reaches 64 per cent. Tobin's Q rises again slightly as managerial ownership increases from 64 per cent. These two turning points are higher than those detected by Cho (1998) and Morck et al. (1988), who used Fortune 500 data from an earlier period. The authors argue that, due to the evolution of corporate governance and changes of regulation in China's market environment, the managerial control for pursuing self-interest and alignment of interests between managers and other shareholders can only be approached by management holding more ownership than is the case in other developed countries.

The association between managerial ownership and capital structure is also nonmonotonic.

A negative relationship exists between managerial ownership and leverage ratios when managerial ownership is below 18 per cent or above 46 per cent. Within the managerial ownership range 18to 46 per cent, the leverage ratio increases as managerial ownership increases. At a low level of managerial ownership (less than 18 per cent for Chinese civilian-run listed companies), managers' behavior is dominated by external discipline and internal controls. For example, managers can be removed because of poor performance. Therefore there are sufficient incentives for managers to adopt financial policies, such as debt 
decisions, that avert financial distress and achieve better firm performance. As the level of managerial equity ownership rises beyond a certain level (approximately 18 per cent), managerial objectives begin to be entrenched. Internal mentoring and external discipline become weak.

This lack of disciplinary control over management may strengthen managers' ability to pursue their own benefits at the cost of decreasing firm value by using suboptimal corporate policies. As the level of managerial ownership reaches a relatively high value (in the study, at 46 and 64 per cent), managers align their interests with those of other shareholders (for example, using less debt to avoid the firm being purchased).

By using a simultaneous equation regression, the authors found that managerial ownership does not influence firm value significantly when capital structure is added into the equation.

Managerial ownership significantly affects capital structure, and capital structure affects corporate performance directly. These results address the influence of managerial shareholding on capital structure, which in turn affects firm value. Furthermore, capital structure is endogenously determined by both firm value and managerial ownership.

So it appears that the managerial ownership could be affected by the debt level of the company. Thus, from the studies just mentioned, we formulate our hypothesis about the interaction between capital structure and managerial ownership as follows:

$\mathrm{H}_{1}$ : There is a nonlinear "inversed N" shape between managerial ownership and capital structure, which represents the change of the managers' incentive motivated by their ownership in the firm.

$\mathrm{H}_{2}$ : the debt level has a negative impact on the managerial ownership

\subsection{Debt policy, growth opportunities and risk free cash flow}

The role of debt monitoring in reducing the agency costs of free cash flow is well emphasized in the theoretical and empirical literature.

Jensen [1986, page 323] defines the free cash flow, as the "cash flow in excess of that required to fun all projects that have positive NPV'. He says that managers may use free cash flow to invest in negative NPV projects rather than return the free cash flow to the shareholders, for example as dividends. This problem is especially bad in firms who are mature and with low growth opportunities, as they have low profitable investments. However, by increasing debt with its required interest payments, managers are "bonding their promise to pay out future cash flows". Jensen indicates that firms with excess cash flows and low growth opportunities will use more debt financing for monitoring purposes. Stulz (1990) also suggested positive relation between leverage and free cash flow. But their theories find no support from empirical research of Chaplinsky and Niehaus (1990).

Also, Hart and Moore (1995) suggest that the debt doesn't resolve the overinvestment problem by the reduction of the free cash flow but rather it is its priority statute that limits the external amount can be collected by the firm. 
Empirically, Lang and al. (1996) find a negative relationship between the leverage and the growth opportunities in firms with low growth opportunities in accordance with the free cash flow theory and find that changes in free cash flow lead to positive changes in leverage in the 142 American listed firms from 1970 to1989.

Gul and Jaggi (1999) develop a composite IOS measure by conducting a common factor analysis on six growth variables in order to classify firms with growth opportunities. The authors use data from 1989 to 1993 to non-regulated industrial firms. Results indicate that the debt has a positive effect on free cash flow firms with low growth opportunities in terms of the bottom quartile of IOS.

Vilasuso and Minkler (2001) develop a dynamic model that incorporates the issues of agency cost and asset specificity. Results based on an unbalanced panel of 28 publicly-held firms show that these two factors are significant determinants of the optimal capital structure of firms. Moreover, results show that agency costs increase with degree of assets specificity.

De Jong and van Dijk (2007) empirically examine the determinants of leverage and agency problems, and they test the relations between leverage and four agency problems i.e. direct wealth transfer, asset substitution, underinvestment and overinvestment. Based on a sample of Dutch firms from 1992 to 1997, the results prove that the trade-off between tax advantages and bankruptcy costs determines leverage. Moreover, free cash flow and corporate-governance characteristics appear to be determinants of overinvestment. Despite findings that agency problems are present, there is no evidence for any relationship between agency problems and leverage.

$\mathrm{Li}$ and cui (2003) test the effect of capital structure on agency costs in 211 non-financial Chinese listed firms for the period from 1999 to 2001. Based on a system of simultaneous equations, results prove that firms with high debt to asset ratio have high ratio of annual sales to total assets and high ratio of return-on-equity. In this case, creditors are more concerned about the payment of interest and of principal and will have incentives to monitor the firm. Consequently, a capital structure with high debt decreases agency costs. Results also show a Positive relationship between ownership concentration and the return-on-equity ratio. This is because the blockholders have a strong interest in firm performance and therefore a high capability to monitor manager in order to reduce agency costs.

Wu (2004), using 833 observations of listed Japanese firms for the period 1992-2000 tests the disciplinary role of ownership structure in corporate capital structure policy. Estimating OLS regression with leverage ratio as the dependent variable and several independents variables which are ownership structure, free cash flow, and growth opportunities, the results confirm that the leverage has a positive effect on free cash flow greater for firms with low growth opportunities than firms with high growth opportunities.

Zhang and Li (2008) employ multivariate tests and univariate tests to analyze the hypothesis which suggests that increase of leverage may reduce agency costs. Based on a sample of 323 UK companies, the results confirm that the increase of leverage does reduce agency costs. Nevertheless, when the leverage is sufficiently high, the effect additional increase in leverage 


\section{MInstitute Macrothink $_{\text {Int }}$}

International Journal of Accounting and Financial Reporting ISSN 2162-3082

has a positive and non significant effect on agency costs. Finally, no significant evidence is found when testing whether the effect of leverage on agency costs becomes stronger when the differences of leverages of firms at different leveraged stages getting larger.

Nekhili and al (2009) test the capacity of governance mechanisms, in the limitation of the problem of the free cash flow in case of French firms. By estimating three stage least square simultaneous model, results prove that distribution of dividends - rather than debt level - that leads to reduction of free cash flow risk.

Recently, D'Mello and Miranda (2010) present a direct test of the overinvestment control hypothesis that states that long-term debt influences the degree to which firms overinvest. They do so by examining the pattern of overinvestment in cash and capital expenditure around new debt issues by unlevered firms. Based on a sample of $366 \mathrm{debt}$ issues between the year 1968 and the year 2001 by firms that have been unlevered for at least three years, the results confirm that issuing debt leads to a reduction of overinvestment. Also, this relation is more significant for firms with poor investment opportunities confirming that debt plays an important role in reducing excess investments in firms that have the highest agency problems.

Agostinho and Prudencio (2010) analyze the capacity of the capital structure policy, the dividend policy, the board and the ownership structure and the practices of social responsibility in the limitation of the free cash flow risk. Using a sample of 298 firms of the NYSE Euronext of the year 2007, the results show that corporate governance mechanisms limit the arbitrariness of the management. In particular, the results confirm the role of leverage in reducing agency costs of free cash flow.

Based on these theoretical and empirical works, the following hypothese apply:

$\mathrm{H}_{3}$ : Leverage is positively related to free cash flow in the firms with low growth opportunities and generating free cash flows.

\section{Interactions between debt policy and managerial ownership: Evidence From Tunisian Stock Exchange}

After confronting the theoretical and empirical literature on the impact of ownership structure on the level of debt, we will try to test these hypotheses in the Tunisian context. Our main objective is to study the relationship between ownership structure and the debt policy as a governance mechanism. To do this, we first present the sample used, the variables studied and the methodology. Finally, we conclude our empirical study by a presentation and analysis of results.

\subsection{Sample selection}

Our sample consists of firms listed on the Tunisian stock exchange. Because banks and insurances are subject to specific rules and regulations, their leverage is severely affected by exogenous factors. So, Following Rajan and Zingales (1995), we exclude all firms categorized as "Financials" and focus exclusively on non-financial firms. Moreover, we eliminated firms not having long term debts (variable important of the model). Data used is provided by the Tunisian Stock Exchange and the Council of Capital Market through 
respectively their official bulletins and their annuals reports covering the period from 1999 to 2009. The analysis is about the period from 2000 to 2009 . The year 1999 serves to calculate some parameters that are variations. Our final sample consisted of 35 firms with a total of 206 firm year observations.

\subsection{Definition of the variables}

\subsubsection{Dependent variables}

\section{Leverage}

Surprisingly, there is no clear-cut definition of leverage in the academic literature. The specific choice depends on the objective of the analysis. On one hand, the total debt ratio has been used by several authors (Kremp and Stöss (2001) and Hovakimian 2005). Whereas Rajan and Zingales (1995) asserts that a ratio that includes the total debts doesn't constitute a good indicator, notably to put in exergue risks of bankruptcy of the firm. However, the short-term debt ratio has also been used by Titman and Wessels (1988). On another hand, some authors use the market value of debts as Taggart (1977), Titman and Wessels (1988), Flannery and Rangan (2006). Other authors as Benett and Donnelly (1993), Chang, Lee and Lee (2008), Huang and Song (2006) used both market value and book value of debt. In our study, we use the same definition of leverage as Lang et al(1996), namely the ratio of the book value of long-term debt to the book value of total assets in order to not neutralize the impact of agency costs joined to the leverage(Myers, 1977). This measure would not reflect recent changes in the markets. This measure has been used by Mello and Miranda (2010) who investigate the role of long-term debt in influencing over investments by analyzing the pattern of abnormal investments around a new debt offering by unleveraged firms. Pao (2008) precise that all studies that are interested in determinants of the capital structure judged that the difference between the market value of debt is very close to book value of debt.

Leverage $=\frac{\text { book value of long term debt }}{\text { book value of total assets }}$

\section{Managerial ownership}

Like Farinha and Lopez-de-Foronda (2009), we use as a measure of managerial ownership percentage of capital held by the managers and members of the Board of Directors.

The variables "DIR", "DIR " and "DIR", which represent the percentage of shares, the square and the cube of the percentage of shares held by the managers respectively, will be used to capture the non-linear relationship between managerial ownership and debt levels. To be consistent with the proposed by previous studies, as Keasy and Short (1999), Braisford et al (2004) and Ruan and Tian Ma (2009) non-linear relationship. Coefficients to estimate for variables DIR and $\mathrm{DIR}^{3}$ should be negative, and that of the variable $\mathrm{DIR}^{2}$ should be positive. 


\section{$\Lambda$ Macrothink}

International Journal of Accounting and Financial Reporting

\subsubsection{Independent variables}

The variables to be included in the equation for the managerial ownership

In this section, we will define the factors that have an impact on the managerial ownership. Like Huson (2006), with debt, the regression Eq (DIR) includes the size, the level of free cash flow, growth, profitability, the risk and institutional ownership.

Institutional ownership

This variable represents the importance of control of the manager. Institutional investors hold a significant stake in the company are involved in the control and management of the company and seek to improve its performance. The assumption of substitutability implies that the optimal managerial ownership is expected to decrease with increasing control by institutional investors. A negative coefficient is then expected to institutional ownership.

Free cash flow

The presence of free cash flow could increase agency costs since be used at the discretion of managers (Jensen, 1986). Thus, the participation of managers in the capital of the company could reduce these costs because when the managerial ownership increases, there is an alignment of their interests with those of shareholders assuming a greater ability to less waste. So, in the presence of these flows, the managerial ownership would be a possible solution to minimize these agency costs. We expect the existence of a positive relationship between property management and free cash flow.

\section{Firm size}

When the firm size increases, a relatively small proportion of shares is owned by managers and this because of their limited personal wealth, constraints on personal loan as well as the problem of diversification. So we expect a negative impact of the firm size on managerial ownership.

\section{Firm Growth}

The managers have a better understanding of the situation of the company and to undertake projects than external shareholders. From the moment the asset growth reflects increased profitability and future performance, managers would be more incentive to invest in the capital of the company. Indeed, they will be more motivated than other investors to bet on growth prospects because of the quality of the information they hold. So, we expect a positive impact of the variable measuring the firm growth on managerial ownership

Firm performance

Kole (1994) suggests that good financial performance should encourage managers to invest more in the company and to prefer equity compensation. Consequently, we expect a positive impact of the variable measuring the performance on managerial ownership. 


\section{$\Lambda$ Macrothink}

International Journal of Accounting and Financial Reporting

Operational risk

Managers are recognized by their aversion to risk and if the risk of exploitation increases, managers are urged to limit their equity to minimize the loss of their wealth. Therefore, the expected sign of the coefficient measuring the risk variable is negative.

The variables to be included in the equation for the debt policy

Harris and Raviv (1991) imply that the leverage of firms may be affected by many factors as investment opportunities, advertising expenditures, fixed assets, and the possibility of bankruptcy, profitability and uniqueness of product. For our empirical purposes, we focus on state ownership, size, tangibility, tax, growth opportunities, profitability, risk and industry classification.

State ownership

Previous research examining the relationship between debt policy and state ownership show that although the state ownership increases the issuance of debt by the company it has adverse effects on motivation and discipline managers and also on the firm performance ( Dewenter and Malatesta , 2001; Khwaja and Mian , 2005) and banks make decisions to grant loans to company owned by the state on the basis of political reasons ( Sapienza , 2004; Dinç, 2005). Wiwattanakantang (2000) showed that in Thai firms , ownership and control mechanisms have significant effects on the financial structure. Firms whose property is majority owned by the state are the most indebted. This is because the loans are secured by the government. The same result has been justified empirically by Lin and Huang (2009) who, studying the impact of state ownsership in China on the debt policy. The authors showed that a high degree of the state ownership can help to improve the ability of the company to borrow since the debt in this case is secured by the government. Also, Li et al (2009), exploring the role of ownership structure and institutional development of the debt of non- state trading firms in China during the period 2000-2004 showed a positive relationship between the state ownership and the level of long-term debt .

We therefore expect a positive impact of the variable "state ownership" and debt levels

Firm size

Theoretically, the effect of size on leverage is ambiguous. On the one hand, some authors find a positive relationship between size and leverage, for example Rajan and Zingales (1995), Huang and Song (2002), Delcoure (2007) and Pao (2008). Larger firms are much more diversified than smaller one and so have lower variance of earnings, making them able to accept high debt ratios. On the other hand, some studies report a negative relationship, for example Kim and Sorensen, (1986), Titman and Wessels, (1988), Fluck et al. (2000) and Chen (2004). Due to asymmetry information, small firms are more likely to be underpriced by investors than large firms and could not get favorable price when financing through equity (Halov and Heider, 2005). While using debt with a fixed interest rate, small firms could suffer less loss from mispricing. Thus small firms should tend to consider using more debt, compared to large firms. 
Tangibility

Booth et al. (2001) state: "The more tangible the firm's assets, the greater its ability to issue secured debt." Consequently, a positive relationship between tangibility and leverage is presumed since tangible assets can be used as collateral. Also, in the case of conflict of interest between shareholders and creditors, Jensen and Mecklings (1976) demonstrated that the problem of overinvestment is less serious with more tangible assets.

Several empirical studies confirm this suggestion (Rajan and Zingales (1995), Kremp et al., (1999), Hovakimian et al., (2001), Chen (2004), Drobetz and Fix (2005), Fattouh et al., (2005), Huang and Song (2006), Delcoure (2007), Pao (2008), De Jong et al., (2008)). On the other hand, Booth et al. (2001) suggest that the relationship between tangible fixed assets and debt financing is related to the maturity structure of the debt. In such a situation, the level of tangible fixed assets may facilitate to the firms to get more long-term debt, but the agency problems may become more severe with the further tangible fixed assets, because the information revealed about future earnings is less in these firms. In this case, a negative relationship between tangible fixed assets and debt ratio is presumed.

\section{Taxation}

Numerous empirical studies have explored the impact of taxation on corporate financing decisions. According to the trade-off theory, a firm with a higher tax rate should issue more debt since it has more income to shield from taxes. However, for example Fama and French (1998) declare that debt has no net tax benefits. MacKie-Mason (1990) also stipulates: "Nearly everyone believes taxes must be important to financing decision, but little support has been found in empirical analysis."

Empirically, Graham and Tucker (2006) use a sample of 44 tax shelter cases to examine the degree of tax shelter activity and whether participating in a shelter is associated to debt policy. The results show that the firms use less debt when they engage in tax sheltering. The tax shelter firms appear under levered if shelters are ignored but do not appear under levered once shelters are considered.

Buettner et al. (2009), test the impact of taxes on the capital structure of German firms. The empirical analysis confirms that the local tax burden exerts important effects on an affiliate's leverage. This refers not only to external debt; the results show that a higher local tax has a positive impact on internal debt. This confirms that multinationals have access to other instrument which can be used to exploit the tax savings opportunities of debt finance.

Growth opportunities

Jensen (1986) suggests that in case of low growth opportunities agency costs of free cash flow rise, so, debt should be issued. In doing so, probability of overinvestment by managers is reduced as firms commit to utilize future free cash flows for paying out investors. Consequently, a negative relationship between growth opportunities and debt ratios can be predicted.

Myers (1977) indicates that high leverage reduces the incentives of the managers and 


\section{MInstitute Macrothink $_{\text {Int }}$}

International Journal of Accounting and Financial Reporting ISSN 2162-3082 2013, Vol. 3, No. 2

shareholders to invest in profitable investment opportunities, since the benefits return to the bondholders rather than to the shareholders. Thus, highly levered firm are less likely to exploit valuable growth opportunities as compared to firm with low levels of leverage. So the values of stocks diminish when there is information that the firm will issue stocks according to the asymmetric information theory. In this case, firms should not issue stocks and must use all internal resources and then financing via debt according to the pecking order theory.

Empirically, Aivazian et al (2005) examine the effect of leverage on investment on 1035 Canadian industrial firms for the period from 1982 to 1999. They found a negative relationship between investment and leverage and that the relationship is more significant for low growth firms rather than high growth firms. Chen and Zhao (2006) find a non-monotonic and positive relationship between growth opportunities and leverage for more than $88 \%$ of COMPUSTAT firms. Billett et al. (2007) conclude that although growth opportunities negatively affect the leverage, there is a positive relationship between leverage and growth opportunities because of covenant protection. Debt covenants may attenuate the negative effect by attenuating the agency costs of debt for firms with high growth opportunities.

\section{Profitability}

There are no consistent theoretical predictions on the effects of profitability on leverage. According to the trade-off theory, more profitable firms should have higher leverage because they have more income to shield from taxes. Also, according the free cash-flow theory would suggest that more profitable firms should use more debt in order to discipline managers. However, from the point of view of the pecking-order theory, firms prefer internal financing to external. Thus more profitable firms have a lower need for external financing and consequently should have lower leverage.

Most empirical studies observe a negative relationship between leverage and profitability, for example (Rajan and Zingales, 1995), (Huang and Song, 2002), (Booth et al., 2001), De Jong et al., (2008) and Karadeniz et al., (2009)

Firm risk

Several authors stipulate that the level of leverage is a decreasing function of the gain variability. The negative relation is predicted by the Trade-off theory, the pecking order theory and the agency theory. Indeed, in a hierarchical financing perspective the volatility of profits can allow the firm to form a reserve of assets easily mobilizable in order to avoid an overinvestment problem. However, there are arguments demonstrating the effect positive of the risk on the leverage. Indeed, firms having a higher risk can also have a strategy of overinvestment that creditors have difficulty discerning because of the asymmetry of information between lenders and borrowers and will to reduce costs of agency. Huang and Song (2002) suggest based on findings of Hsia (1981): "As the variance of the value of the firm's assets increases, the systematic risk of equity decreases. So the business risk is expected to be positively related to leverage."

Empirically, the effect of risk on leverage is ambiguous. On the one hand, some authors find an inverse relationship between risk and leverage, for example Bradley et al., 1984; Titman 


\section{Mll Macrothink}

International Journal of Accounting and Financial Reporting

ISSN 2162-3082

2013, Vol. 3, No. 2

and Wessels, 1988; Friend and Lang, 1988; MacKie-Mason, 1990; Kale et al., 1991; Kim et al., 1998). Other studies suggest a positive relationship (Jordan et al., 1998; Michaelas et al., 1999; Wiwattanakantang, 1999; Kremp and Stöss, 2001; Esperança et al., 2003 and Pao, 2008).

\section{Industry Classification}

Some empirical studies identify a statistically significant relationship between industry classification and leverage. Titman (1984) and Titman and Wessels (1988) show that firms manufacturing machines and equipment should be financed with relatively less debt, because they incur some very important liquidation costs. They use a dummy variable equal to one if the firm belongs to the industry sector and zero otherwise. Harris and Raviv (1991) declare, based on a survey of empirical studies: "Drugs, Instruments, Electronics, and Food have consistently low leverage while Paper, Textile Mill Products, Steel, Airlines, and Cement have consistently large leverage". More recently Awan and al., (2010) examine the relationship between growth opportunities and capital structure of the firms for sample of 110 manufacturing companies listed on Karachi Stock Exchange for 15 years (1982-1997) from 9 different sectors. They have found a significant positive relationship between growth opportunities and leverage that is greatly significant for sectors such as textile, sugar, cement, paper and jute. The possible explanation for such leverage behavior in these sectors could be that the owners of these firms, with a nominal foreigners' representation view the available growth opportunities as unsustainable and more risky, intend to pass on a higher risk to their creditors which would result in a high debt level. However, some empirical studies find no significant relationship between leverage and industry classification, we essentially mention the study of Drobetz and Fix (2005) for the Swiss firms and the one of Kim, Heshmati and Aoun (2006) for the non financial listed firms in Korea. For the Tunisian firms, the industrial sector grants a big importance to restructurings requiring some enormous amounts.

To estimate our models we must examinate if there is presence of a multicollinearity problem.

Multicollinearity refers to a situation in which two or more explanatory/independent variables in multiple regression models are highly correlated. It can be detected through analyzing the Pearson correlation matrix. If the Pearson correlation coefficient exceed 0,7 (limit fixed by Kervin, 1992), we conclude the presence of multicollinearity. 


\section{Macrothink}

International Journal of Accounting and Financial Reporting

ISSN 2162-3082

2013, Vol. 3, No. 2

Table 1: the correlation matrix of the independent variables

\begin{tabular}{|l|l|l|l|l|l|l|l|l|l|l|l|l|l|l|}
\hline & Man & Inst & State & Size & Fix & Tax 1 & Tax 2 & FCF & Rent & Risk & Qtobin & ROA & leverage & growth \\
\hline Man & 1,000 & & & & & & & & & & & & \\
\hline Inst & 0,233 & 1,000 & & & & & & & & & & & \\
\hline State & 0,359 & 0,402 & 1,000 & & & & & & & & & & \\
\hline Size & 0,329 & 0,050 & 0,315 & 1,000 & & & & & & & & & & \\
\hline Fix & $-0,048$ & 0,186 & 0,206 & $-0,140$ & 1,000 & & & & & & & & \\
\hline Tax 1 & $-0,017$ & $-0,096$ & 0,109 & $-0,208$ & $-0,140$ & 1,000 & & & & & & & & \\
\hline Tax 2 & 0,392 & $-0,047$ & $-0,204$ & $-0,053$ & $-0,137$ & 0,093 & 1,000 & & & & & & & \\
\hline FCF & 0,244 & $-0,130$ & $-0,318$ & $-0,086$ & $-0,107$ & 0,149 & 0,817 & 1,000 & & & & & & \\
\hline Rent & $-0,150$ & $-0,304$ & $-0,374$ & $-0,119$ & $-0,195$ & 0,500 & 0,087 & 0,248 & 1,000 & & & & & \\
\hline Risk & 0,032 & 0,098 & $-0,005$ & $-0,042$ & 0,083 & 0,078 & $-0,033$ & 0,001 & 0,156 & 1,000 & & & & \\
\hline Qtobin & 0,298 & 0,248 & $-0,175$ & 0,016 & $-0,151$ & 0,391 & 0,234 & 0,305 & 0,403 & $-0,035$ & 1,000 & & & \\
\hline ROA & 0,087 & $-0,175$ & $-0,364$ & $-0,097$ & $-0,187$ & 0,512 & 0,223 & 0,385 & 0,934 & 0,137 & 0,411 & 1,000 & & \\
\hline Leverage & 0,345 & 0,394 & 0,339 & 0,157 & $-0,043$ & $-0,282$ & 0,052 & $-0,145$ & $-0,513$ & $-0,004$ & $-0,198$ & $-0,541$ & 1,000 & \\
\hline Growth & $-0,157$ & 0,010 & $-0,127$ & $-0,029$ & $-0,033$ & 0,099 & $-0,077$ & $-0,035$ & 0,186 & $-0,052$ & 0,115 & 0,208 & $-0,174$ & 1,000 \\
\hline
\end{tabular}

Table (1) present the correlation coefficient associated to independent variables used in our models.

Results in table (1) indicate that all Pearson correlation coefficients are less than 0,7. Thus, we conclude the absence of a multicollinearity problem.

\subsection{Specification and method of estimation of the model}

A simultaneous equations approach particularly 3SLS is deemed to be appropriate on the basis of the interrelationships among the agency-cost-reducing mechanisms. This study uses a two-equation model with debt ratio and managerial ownership as the dependent variables (Harvey, Lins and Roper, 2004; Huson, 2006; Ghosh, 2007 and Ruan, Tian and Ma, 2009).

$\left\{\begin{array}{l}\text { DR }_{i, t}=\beta_{0}+\beta_{1} \text { MGROWN }_{i, t}+\beta_{2} \text { MGROWN }_{i, t}{ }^{2}+\beta_{3} \text { MGROWN }_{i, t}{ }^{3}+\beta_{4} \text { State }_{, t}+\beta_{5} \text { Growth }+\beta_{6} \\ \text { Size }_{i, t}+\beta_{7} \text { Tang }_{i, t}+\beta_{8} \text { Tax }_{i, t}+\beta_{9} \text { FCF }_{i, t}+\beta_{10} \text { Profit }_{i, t}+\beta_{11} \text { Risk }_{i, t}+\beta_{12} \text { Ind }_{i, t}+\varepsilon_{1, t}\end{array}\right.$ (1)

MGROWN $_{i, t}=\alpha_{0}+\alpha_{1}$ DR $_{i, t}+\alpha_{2}$ Inst $_{i, t}+\alpha_{4}$ Size $_{i, t}+\alpha_{5}$ FCF $_{i, t}+\alpha_{6}$ ROA $_{i, t}+\alpha_{7}$ Risk $_{i, t}+\alpha_{8}$ Growth $_{i, t}$

(2)

$\varepsilon_{1 \mathrm{it}}=\mathrm{a}_{1 \mathrm{i}}+\mu_{1 \mathrm{it}}$
$\varepsilon_{2 \mathrm{it}}=\mathrm{a}_{2 \mathrm{i}}+\mu_{2 \mathrm{it}}$
$\mathrm{i}=1, \ldots \ldots \ldots \ldots . .$. $\mathrm{N}$ and $\mathrm{t}=1$, T

$\varepsilon_{1 i t}$ and $\varepsilon_{2 i t}$ : Error Term corresponding respectively to the first and to the second equation, 


\section{MIN Macrothink}

International Journal of Accounting and Financial Reporting ISSN 2162-3082 2013, Vol. 3, No. 2

$\beta_{1} \ldots \ldots \beta_{12}$ : representative parameters of the relative weight of each exogenous variable on the variable to explain «Debt Ratio».

$\alpha_{1} \ldots \ldots \alpha_{8}$ : representative parameters of the relative weight of each exogenous variable on the variable to explain «Managerial ownership »;

$\mathrm{N}$ : the number of firms and $\mathrm{T}$ : the estimation period.

\subsubsection{The identification condition in the model}

Order conditions are verified when the number of endogenous variables $\left(k-k^{\prime}\right)$ plus the number of exogenous variables $\left(\mathrm{g}-\mathrm{g}^{\prime}\right)$ is more or equal to the number of equations less 1 : $(\mathrm{k}$ $\left.\mathrm{k}^{\prime}\right)+\left(\mathrm{g}-\mathrm{g}^{\prime}\right) \geq(\mathrm{e}-1)$.

The equation is over - identified if $\left(\mathrm{k}-\mathrm{k}^{\prime}\right)>\left(\mathrm{g}^{\prime}-1\right)$

The equation is under - identified if $\left(\mathrm{k}-\mathrm{k}^{\prime}\right)<\left(\mathrm{g}^{\prime}-1\right)$

The equation is exactly identified if $\left(\mathrm{k}-\mathrm{k}^{\prime}\right)=\left(\mathrm{g}^{\prime}-1\right)$

With:

$\mathrm{g}$ : number of endogenous variables of the model;

k: number of exogenous variables of the model;

g': number of endogenous variables introduced in an equation;

$\mathrm{k}^{\prime}$ : number of exogenous variables introduced in an equation;

Rank conditions assure here that the reduce form of model possesses a solution unique. The rank conditions for empirical identification are relatively complicated.

A simultaneous linear equation model is identified if all the equations are identified

Table 2: The identification condition in the model

\begin{tabular}{|l|l|l|l|l|l|l|l|}
\hline Equation & $\mathbf{g}$ & $\mathbf{K}$ & $\mathbf{g}^{\prime}$ & $\mathbf{k}{ }^{\prime}$ & $\mathbf{k}-\mathbf{k}^{\prime}$ & $\mathbf{g}^{\prime}-1$ & Identification \\
\hline $\begin{array}{l}\text { Equation } \\
1\end{array}$ & 2 & 14 & 2 & 12 & 2 & 1 & $\begin{array}{l}\text { k-k'= g'-1; the equation I is over } \\
\text { identified }\end{array}$ \\
\hline $\begin{array}{l}\text { Equation } \\
2\end{array}$ & 2 & 14 & 2 & 7 & 7 & 1 & $\begin{array}{l}\text { k-k' }>\text { g'-1; the equation II is over } \\
\text { identified }\end{array}$ \\
\hline
\end{tabular}

\subsubsection{Method of estimation}

Parameters can be estimated when equations are exactly-identified or are over - identified. We make a distinction between incomplete information method and complete information method. The first one consists in estimating equation by equation the model by the two stage least square method. The second one considers the model in its entirety and we use here the 


\section{Macrothink}

International Journal of Accounting and Financial Reporting

ISSN 2162-3082 2013, Vol. 3, No. 2

three stage least square method (Cadoret et al. (2004)). Our model will be estimated by the three stage least square method with 206 observations on the period 2000-2009. The system of three simultaneous equations, for every firm i and every year $\mathrm{t}$, can be:

$y=Z \delta+\varepsilon$

$y=\left[\begin{array}{l}y_{1} \\ y_{2}\end{array}\right]=\left[\begin{array}{cc}Z_{1} & 0 \\ 0 & Z_{2}\end{array}\right]\left[\begin{array}{l}\delta_{1} \\ \delta_{2}\end{array}\right]+\left[\begin{array}{l}\varepsilon_{1} \\ \varepsilon_{2}\end{array}\right]$

as :

$y^{\prime}=\left(y_{1}, y_{2}\right)$ is vector of endogenous variables (Debt ratio, Managerial ownership)

Vectors of the explanatory endogenous and exogenous variables of the equation of debt ratio $\mathrm{Z}_{1}$, and managerial ownership $\mathrm{Z}_{2}$ are:

$\left\{\begin{array}{l}\text { DR }_{i, t}=\beta_{0}+\beta_{1} \text { MGROWN }_{i, t}+\beta_{2} \text { MGROWN }_{i, t}{ }^{2}+\beta_{3} \text { MGROWN }_{i, t}{ }^{3}+\beta_{4} \text { State }_{t}+\beta_{5} \text { Growth }^{+} \beta_{6} \\ \text { Size }_{i, t}+\beta_{7} \text { Tang }_{i, t}+\beta_{8} \text { Tax }_{i, t}+\beta_{9} \text { FCF }_{i, t}+\beta_{10} \text { Profit }_{i, t}+\beta_{11} \text { Risk }_{i, t}+\beta_{12} \text { Ind }_{i, t}+\varepsilon_{1 i, t}\end{array}\right.$ (1)

$M_{G R O W N} i_{i, t}=\alpha_{0}+\alpha_{1} D R_{i, t}+\alpha_{2}$ Inst $_{i, t}+\alpha_{4}$ Size $_{i, t}+\alpha_{5} F C F_{i, t}+\alpha_{6} R_{O A A_{i, t}}+\alpha_{7}$ Risk $_{i, t}+\alpha_{8}$ Growth $_{i, t}$

(2)

$Z_{1}=$

[ MGROWN,MGROWN ${ }^{2}$,MGROWN3, State, Growth, Size,Tang, Tax,FCF, Profit, Risk, Ind]

$Z_{2}=[$ DR, Inst, Size, FCF, ROA, Risk, Growth $]$

For error term :

$E(\varepsilon)=0$

$E\left(\varepsilon \varepsilon^{\prime}\right)=\left[\sigma_{s h} I\right]$ is the variance-covariance matrix

In the case of the simultaneous equations, the interdependence of endogenous variables deal place to an interdependence of error terms, what calls at the time of the estimation on the three least square method. This method is based in estimating the system in three stages. The first two stages are those of the 2SLS method applied separately to every equation of the system under its reduced form. Then, in our case we have two equations to estimate. The reduced form of the system is gotten by the application of the following stages: while using vectors, we can identify a matrix $B$ of two endogenous variable coefficients and a matrix $A$ of 


\section{MIN Macrothink}

exogenous variable coefficients as:

$$
\begin{aligned}
& y^{\prime}=(B-I)^{\prime}+X^{\prime} A=\varsigma \\
& y^{\prime}=-X^{\prime} A(B-I)^{t-1}+\varsigma^{\prime}(B-I)^{t-1} \\
& y^{\prime} \equiv X^{\prime} \Pi+v \\
& \Pi \equiv-A^{\prime}(B-I)^{t-1} \\
& \Pi_{h} \quad \text { and } \Pi_{h}^{\prime} \text { the standard elements of the matrix } \\
& v^{\prime} \equiv \varsigma(B-I)^{t-1}
\end{aligned}
$$

The variance-covariance matrix of error terms $E\left[v v^{\prime}\right]$ is:

$$
E\left[v v^{\prime}\right]=(B-I)^{-1} \sum \Omega I(B-I)^{t-1}
$$

Then, the reduced form of the explicit system is the following:

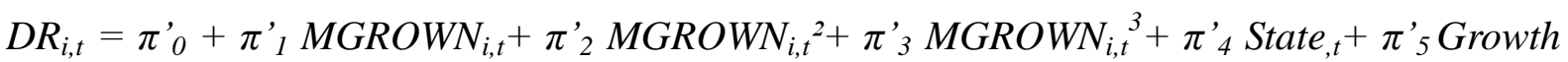
$+\pi_{6}{ }_{6}$ Size $_{i, t}+\pi{ }_{7}$ Tang $_{i, t}+\pi{ }_{8}$ Tax $_{i, t}+\pi{ }_{9}$ FCF $_{i, t}+\pi^{\prime}{ }_{10}$ Profit $_{i, t}+\pi^{\prime}{ }_{11}$ Risk $_{i, t}+\pi_{12}{ }_{12}$ Ind $_{i, t}+v$ ' $1 i, t$

$\operatorname{MGROWN}_{i, t}=\pi^{\prime}{ }_{0}+\pi^{\prime}{ }_{1} \mathrm{DR}_{i, t}+\pi^{\prime}{ }_{2}$ Inst $_{i, t}+\pi^{\prime}{ }_{4}$ Size $_{i, t}+\pi^{\prime}{ }_{5} \mathrm{FCF}_{i, t}+\pi^{\prime}{ }_{6}$ ROA $_{i, t}+\pi^{\prime}{ }_{7}$ Risk $_{i, t}$ $+\pi^{\prime}{ }_{8}$ Growth $_{i, t}+v^{\prime}{ }_{2 i, t}$

Now, evaluation is done by applying the ordinary least square method, and we obtain $\hat{\Pi}$ the estimator of $\Pi$

$$
\hat{\Pi}=\left(X^{\prime} X\right)^{-1} X^{\prime} y
$$

This method permits us to get values $\hat{y}_{1}$, and $\hat{y}_{2}$ serving to get the instrumental variables in the two equations. The following procedure consists in estimating every equation of the structural system while using the gotten instruments while applying the two least square method (2SLS). So, we find an estimator $\hat{\sigma}_{s}$. The objective will be to construct the estimated matrix of variance - covariance matrix of error terms that is going to be used like ponderation matrix whose basic element $\hat{\sigma}_{i j}$ is: 
$\hat{\sigma}_{i j}=\frac{\left(y_{i}-Z_{i} \hat{\delta}_{i}\right)\left(y_{j}-Z_{j} \hat{\delta}_{j}\right)}{n}$

$\mathrm{n}$ : the number of years.

The last stage consists in estimating simultaneously the two equations with the triple least square method (3SLS).

\section{Empirical results and discussion}

\section{Three stage least square results}

Results of the joint estimation of debt ratio and managerial ownership are presented at panel A, panel and B of Table 3 .

Table 3 : Estimated coefficients for the debt and managerial ownership :Thtree-Stage Least Squares Method (3SLS)

Equation 1:DR $R_{i, t}=\beta_{0}+\beta_{1} M_{G R O W N}+\beta_{2} M_{\text {MROWN }}{ }^{2}+\beta_{3} \operatorname{MGROWN}_{i, t}{ }^{3}+\beta_{4}$ State $_{, t}+\beta_{5}$ Growth $+\beta_{6}$ Size $_{i, t}+\beta_{7}$ Tang $_{i, t}+\beta_{8}$ Tax $_{i, t}+\beta_{9}$ FCF $_{i, t}+\beta_{10}$ Profit $_{i, t}+\beta_{11}$ Risk $_{i, t}+\beta_{12}$ Ind $_{i, t}+$ $\varepsilon_{1 i, t}$

\begin{tabular}{|l|l|l|l|}
\hline Variables & Coefficient & t-Statistic & Prob. \\
\hline MGROWN & $-6,83^{* *}$ & $-2,21$ & 0,027 \\
\hline MGROWN & $18,118^{* *}$ & 2,08 & 0,038 \\
\hline MGROWN & $-12,165^{* *}$ & $-2,02$ & 0,043 \\
\hline State & $0,126 *$ & 1,90 & 0,058 \\
\hline Size & $-0,046$ & $-1,15$ & 0,248 \\
\hline Tang & $-0,113$ & $-0,59$ & 0,554 \\
\hline Tax & 0,114 & 0,53 & 0,600 \\
\hline Growth & 0,039 & 0,24 & 0,809 \\
\hline FCF & $-0,052$ & $-0,17$ & 0,868 \\
\hline Profit & $-1,093^{* *}$ & $-2,23$ & 0,025 \\
\hline Risk & 0,102 & 0,38 & 0,706 \\
\hline
\end{tabular}




\begin{tabular}{|l|l|l|l|} 
Ind & 0,112 & 1,18 & 0,236 \\
\hline Number of observations & 206 \\
\hline $\mathbf{R}^{\mathbf{2}}$ & $50,23 \%$ \\
\hline
\end{tabular}

Equation 2:MGROWN $N_{i, t}=\alpha_{0}+\alpha_{1} D R_{i, t}+\alpha_{2}$ Inst $_{i, t}+\alpha_{4}$ Size $_{i, t}+\alpha_{5} F C F_{i, t}+\alpha_{6}$ ROA $_{i, t}+\alpha_{7}$ Risk $_{i, t}+\alpha_{8}$ Growth $_{i, t}+\varepsilon_{2 i, t}$

\begin{tabular}{|l|l|l|l|}
\hline Variables & Coefficient & t-Statistic & Prob. \\
\hline Dette & $0,564 * * *$ & 6,27 & 0,000 \\
\hline Inst & $-0,039$ & $-0,44$ & 0,661 \\
\hline Taille & $-0,08^{* *}$ & $-3,38$ & 0,001 \\
\hline FCF & 0,114 & 0,58 & 0,564 \\
\hline ROA & $0,780 * *$ & 2,50 & 0,013 \\
\hline Risk & $-0,171^{*}$ & $-1,91$ & 0,056 \\
\hline Croiss & 0,077 & 0,69 & 0,490 \\
\hline $\begin{array}{l}\text { Number } \\
\text { observations }\end{array}$ & 206 & $18,89 \%$ & \\
\hline R & & & \\
\hline
\end{tabular}

\subsection{The determinants of debt policy}

Our results show that variables "Dir ", "Dir ${ }^{2 "}$ and "Dir" 3 " are all significant and have the expected signs. The coefficients of the variables "Dir" and " $\mathrm{Dir}^{3}$ " are negative while the coefficient of the variable " $\operatorname{Dir}^{2}$ " is positive. So, the association between managerial ownership and capital structure is nonmonotonic.

Furthermore we tried to determine the two inflection points defined in terms of managerial ownership. The point of inflection of the non-linear relationship is obtained by canceling the first derivative of the equation linking debt to managerial ownership, its square and its cube. The values that we obtain are $25 \%$ and $74 \%$ respectively. So, a negative relationship exists between managerial ownership and leverage ratios when managerial ownership is below 25 per cent or above 74 per cent. Within the managerial ownership range 25to 74 per cent, the 
leverage ratio increases as managerial ownership increases.

Table 5: inflection points

\begin{tabular}{|l|l|l|l|}
\hline & - & + & - \\
\hline $\begin{array}{l}\text { ownership managerial } \\
\text { Average debt }\end{array}$ & $<25 \%$ & {$[25 \%-74 \%]$} & $>74 \%$ \\
\hline Ave & $22,14 \%$ & $27,63 \%$ & $13,18 \%$ \\
\hline
\end{tabular}

Our results show that managers act from alignment to entrenchment and to alignment gradually as their ownership increases. Our results corroborate those of Braisford et al (2004) and Ruan, Tian and Ma (2009). By analogy, we can consider that for low levels (below 25\%), an increase in managerial ownership tend to align their objectives to those of shareholders. So, managers seek to improve business performance by reducing the debt level to reduce the risk of financial distress. Then, when the managerial ownership becomes relatively higher, the majority shareholders can not effectively exert pressure on the managers who become more entrenched by concentrating their voting power and handling debt policy in their interests. For example, managers can increase the level of debt to get more cash to increase the size of the firm beyond its optimal size in order to increase their compensation in parallel. The debt will result in foster entrenchment and limit the effect of dilution of the ownership. Finally, when managers hold very important parts of the capital, their own wealth is increasingly tied to the company. Under these conditions, they prefer to use less debt to protect their personal wealth invested heavily in the company they run. They suffer, in fact, a significant risk due to the problem of under diversification of their financial investment they wish to limit by reducing their use of debt. In this case, the alignment of interests prevails over the entrenchment.

Regarding the control variables, our results show that the coefficient on the "state" variable has a positive and statistically significant effect on debt. Our result confirms that of Lin and Huang (2009) who, studying the impact of state participation in the capital of companies in China on the level of debt, showed a high degree of state wnership improve the ability of the company to borrow since the debt in this case is secured by the government.

Also, the results show a significant and negative relationship between financial profitability and long-term debt. This negative correlation highlights the fact that highly profitable firms need less external funding, which is consistent with the pecking order theory whereby managers prefer to finance primarily by internal resources to reduce agency costs resulting from external funding.

However, contrary to our expectations the coefficient associated with the variable free cash flow is negative and insignificant in the equation of the debt. Our results reject our third hypothesis H3 and contradict Jensen (1986) who suggests that in case of low growth opportunities, agency costs of free cash flow increase, which the debt must be issued. Indeed, 


\section{Mll Macrothink}

International Journal of Accounting and Financial Reporting ISSN 2162-3082 2013, Vol. 3, No. 2

the likelihood that managers make a overinvestment decision is reduced because the company is committed to using free cash flow to pay the providers of funds.

\subsection{Determinants of managerial ownership}

The analysis of the table 3 (managerial ownership equation) shows that the managerial ownership is mainly determined by the level of debt, the firm size, the performance and the level of risk.

The positive and significant sign of the debt in the equation of managerial ownership is not consistent with our expectations and contradicts results of Agrawal and Mandelker (1987) and Huson et al (2006) indicating that the presence of debt leaders in the capital structure of the firm increases its risk and therefore discourages managers to increase their stake in the company. Rather our result corroborates those of Al and Al- Saad Deehani (2006) and Godfrey et al. (2009) who show that debt and managerial ownership are two complementary mechanisms of governance in monitoring managerial behavior and reducing costs agency, and suggest that the financing of investment projects by debt rather than by issuing new shares, consolidating control of the current managers serving in this way as a strategy of resistance against takeover.

For the control variables, we note that only the variable "Size", "profitability" and» Risk" are statistically significant at $1 \%$ levels, $5 \%$ and $10 \%$ respectively according to our expectations. So it seems that managers of listed Tunisian firms prefer to invest their wealth in companies with smaller sizes and more profitable because of their limited personal wealth.

Also, our results show that if the operational risk is high the managers avoid investing their wealth in the capital of the company because of their high risk aversion.

Finally, variables related to institutional ownership and risk free cash flow do not seem to affect the managerial ownership when their coefficients are not significant.

In sum, controlling the endogeneity problem, our results support a significant interaction between ownership structure and capital structure.

\section{Conclusion}

In this study we verified the existence of an interaction effect between debt and managerial ownership, while paying particular attention to the determinants of these two variables and especially to free cash flow. In particular, we are interested in the nonlinear relationship between managerial ownership and debt. To this end, we selected a sample of 35 non-financial companies listed on the stock exchange of Tunis during the period 2000-2009. By estimating a system simultaneous equations by the method tree stage least squares, the results show that the association between managerial ownership and capital structure is nonmonotonic. At a low level of managerial ownership (less than 25 per cent for Tunisian listed companies), managers' behaviour is dominated by external discipline and internal controls. For example, managers can be removed because of poor performance. Therefore there are sufficient incentive for managers to adopt financial policies, such as debt decisions, that avert financial distress and achieve better firm performance. As the level of managerial equity ownership rises beyond a certain level (approximately 25 per cent), managerial 
objectives begin to be entrenched. Internal mentoring and external discipline become weak. This lack of disciplinary control over management may strengthen managers' ability to pursue their own benefits at the cost of decreasing firm value by using suboptimal corporate policies. As the level of managerial ownership reaches a relatively high value (in this study, at 25 and 74 per cent), managers align their interests with those of other shareholders (for example, using less debt to avoid the firm being purchased).

Also, our results show that debt impact positively managerial ownership. So, debt and managerial ownership are two complementary mechanisms of governance in monitoring managerial behavior and too reducing costs agency, and suggest that the financing of investment projects by debt rather than by issuing new shares, consolidating control of the current managers serving in this way as a strategy of resistance against takeover.

So, our results support a significant interaction between ownership structure and capital structure.

Finally, it should be noted that the estimated model does not include all the governance mechanisms that may influence the relationship between capital structure and ownership structure in the problem of overinvestment. The dividend policy and the board of directors are also the main control systems absent in our study.

\section{References}

A.E. Ezeoha, 2008, «Firm size and corporate financial leverage choice in a developing economy», The Journal of Risk Finance, vol. 9(4), pp.351-364.

- Abor, J. 2008. "Agency theories determinants of debt levels: evidence from Ghana". Review of Accounting and Finance, vol. 7, no 2, pp.183-192.

- Abor, J. 2008. "Debt policy and performance of SMEs: Evidence from Ghana and South African firms". The Journal of Risk Finance, vol. 8, no 4, pp.364-379.

- Agrawal A.and Knoeber C.R. (1996), «Firm Performance and Mechanisms to Control Agency Problems between Managers and Shareholders », Journal of Financial and Quantitative Analysis, vol. 31, n³ , p. 377-397.

- Al-Deehani and Al-Saad (2007), «Ownership Structure and Its Relationship with Capital Structure: An Empirical Study on the Companies Listed in the Kuwait Stock Exchange», Arab Journal of Administrative Sciences Arab Journal of Administrative Sciences, Volume 14, Issue 2

- Basil Al-Najjar, Peter Taylor, (2008) "The relationship between capital structure and ownership structure: New evidence from Jordanian panel data", Managerial Finance, Vol. 34, Issue: 12, pp.919 - 933Andrés P., López F.J., Rodríguez J.A. (2005), « Financial Decisions and Growth Opportunities: A Spanish Firms Panel Data Analysis », Applied Financial Economics, vol. 15, n6, p. 391- 407. 


\section{Macrothink}

International Journal of Accounting and Financial Reporting ISSN 2162-3082 2013, Vol. 3, No. 2

- Berger P., Ofek and E., Yermach D. (1997), « Managerial Entrenchment and Capital Structure Decisions », Journal of Finance, vol. 52, n 4, p. 1411-1438.

- Berger, AN and Patti (2006), "Capital structure and firm performance: A new approach to testing agency theory and an application to the banking industry", Journal of Banking \& Finance, vol. 30, no. 4, pp. 1065-102.

- Booth, L., Aivazian, V., Demirguc-Kunt, A. and Maksimovic, V., (2001), «Capital structure in developing countries», Journal of Finance 56, pp. 87-130

- $\quad$ Brailsford, T.J., Oliver, B.R., Pua, S.L.H. (2002), "On the relation between ownership structure and capital structure", Accounting and Finance, Vol. 42, pp. 1-26, 2002

- Buettner, Overesch, Schreiber, Wamser and Georg (2009), «Taxation and capital structure choice: Evidence from a panel of German multinationals», Economics Letters, Volume 105, issue 3, pp. 309-311

- Bunkanwanichay, Guptaz and Rokhimx (2008), «Debt and entrenchment: Evidence from Thailand and Indonesia", European Journal of Operational Research, vol. 185, issue 3 , pages $1578-1595$

- Cadoret, Benjamin, Martin, Herrard and Tanguy (2004), «Économétrie appliquée: méthodes, applications, corrigés», De Boeck Université,452 pages

- Chang, C., Lee, Alice C., and Lee, Cheng F, (2009), «Determinants of capital structure choice: A structural equation modeling approach», The Quarterly Review of Economics and Finance, 49, 197-213.

- Chen, J. J. (2004), «Determinants of capital structure of Chinese-listed companies», Journal of Business Research, 57, 1341 - 1351.

- Chen, X. and Yur-Austin, J. (2007) «Re-measuring agency costs: The effectiveness of blockholders», The Quarterly Review of Economics and Finance, 47:5, pp. 588-601.

- De Jong A., and Dijk R.V. (2007), « Determinants of Leverage and Agency Problems: A Regression Approach with Survey Data », European Journal of Finance, vol. 13, n'6, p. 565-593.

- De Jong, Kabir and Nguyen, (2008), «Capital structure around the world: The roles of firm- and country-specific determinants», Journal of Banking \& Finance Volume 32, Issue 9, September, Pages 1954-1969

- De La Bruslerie H., (2004), “Actionnaires contrôlants, bénéfices privés et endettement", document de travail, Université Paris 1 Panthéon Sorbonne.

- Delcoure N., (2007). «The determinants of capital structure in transitional economies», International Review of Economics and Finance, 16, pp. 400-415.

- Demsetz.H. (1983), «The structure of ownership and the theory of the firm», Journal of Law and Economics, Vol 24, PP.375-390. 


\section{Mll Macrothink}

International Journal of Accounting and Financial Reporting ISSN 2162-3082 2013, Vol. 3, No. 2

- Demsetz.H. and Lehn K. (1985), «The structure of corporate ownership: causes and consequences», Journal of Political Economy, 93 (6), pp.1155-1177.

- Demsetz.H. and Vilallonga B. (2001), «Ownership structure and corporate performance», Journal of Corporate Finance, 7 (3), pp.209-233.

- D'Mello and Miranda, (2010), «Long-term debt and overinvestment agency problem», Journal of Banking and Finance 34, pp. 324-335

- Drobetz W. and Fix R. (2005), «What are the determinants of the capital structure? Some evidence for Switzerland », Revue Suisse d'Economie et de statistique, ${ }^{\circ} 1$, mars, pp. 71-114

- Dutta, Collins and Wansley (2000), “An Examination of the Non-Linear Effects of Insider Ownership on Corporate Policy Choice". Academy of Economics and Finance, Papers and Proceedings, Vol. 23, Twenty-sixth Annual Meetings, Little Rock, Arkansas, February 11-13, 1999, pp. 101-109.

- E. Karadeniz, S. Y. Kandir, M. Balcilar and Y. B. Onal, (2009), «Determinants of capital structure: evidence from Turkish lodging companies», International Journal of Contemporary Hospitality Management, vol. 21(5), pp.594-609

- Farinha and Oscar (2009), «The relation between dividends and insider ownership in different legal systems: international evidence», European Journal of Finance, vol. 15 , issue 2 , pages $169-189$

- Fattouh, Bassam and Scaramozzino, Pasquale et Harris, Laurence, (2005), «Capital structure in South Korea: a quantile regression approach», Journal of Development Economics, Elsevier, vol. 76(1), pages 231-250.

- Flannery, M.J. and K.P. Rangan, (2006), «Partial adjustment toward target capital structures», Journal of Financial Economics, Vol 79, issue 3, mars, pp. 469-506

- Fluck, Z., D. Holtz-Eakin, and H.S. Rosen. (2000) «Where does the money come from? The financing of small entrepreneurial enterprises. », (Working paper, New York University

- Friedman, Simon; and Todd , (2003), "Propping and Tunnelling." Working Paper. Cambridge: MIT Sloan School of Management.

- Garvey G.T. and G. Hanka, (1999), «Capital structure and corporate control : the effect of anti-takeover statutes on firm leverage», Journal of finance, Volume 54 , Issue 2 , pp. 519-546

- Ghosh, S. (2007). Leverage, managerial monitoring and firm valuation: A simultaneous equation approach. Research in Business, 61, 84-98.

- Gorton, G., and R. Rosen, 1995. "Corporate Control, Portfolio Choice, and the Decline of Banking”, Journal of Finance 50: 1377-420. 


\section{Macrothink}

International Journal of Accounting and Financial Reporting ISSN 2162-3082 2013, Vol. 3, No. 2

- Graham, J.R. and Tucker, A.L. 2006, «Tax shelters and corporate debt policy», Journal of Financial Economics, vol. 81, pp. 563-594.

- Gul F.A., Jaggi B., (1999), «An analysis of joint effects of investment opportunity set, free cash flow and size on corporate debt policy », Review of Quantitative Finance and Accounting, vol. 12, $\mathrm{n}^{\circ}$ 4, pp. 371-381.

- Halov N., F. Heider, (2005), «Capital Structure, asymmetric information and risk», EFA 2004 MAASTRICHT, pp. 1-56.

- Harris M. and A.Raviv (1991), «The theory of capital structure», Journal of Finance, Vol 46, Issue 1, pp. 297-355

- Hosono (2003), «Growth Opportunities, Collateral and Debt Structure: The Case of the Japanese Machine Manufacturing Firms», Japan and the World Economy,, vol 15, issue. 3, pp. 275-97

- Hovakimian (2006), «Are Observed Capital Structures Determined by Equity Market Timing? », Journal of Financial and Quantitative Analysis, 2006, vol. 41, issue 01, pp 221-243

- Huang, G. and F.M. Song,. (2006), «The Determinants of Capital Structure: Evidence from China», China Economic Review, 17: pp. 14-36

- Jensen, M., (1986), «Agency costs of free cash flow, corporate finance and takeovers», American Economic Review 76, pp. 323-329

- Jensen, M.and Meckling, W., (1976). «Theory of the firm: Managerial behaviour, agency costs and capital structure», Journal of Financial Economics 3, pp. 305-360

- Kim, H., Heshmati, A., and Aoun, D. (2006), «Dynamics of capital structure: the case of Korean listed manufacturing companies», Asian Economic Journal, 20(3), pp275-302.

- Kremp E.and Stoss E. (2001), «L'endettement des entreprises industrielles françaises et allemandes : des évolutions distinctes malgré des déterminants proches», Economie et Statistique $\mathrm{n}^{\circ} 1 / 2$.

- Kumar, Jayesh, 2004, Debt vs. equity: Role of corporate governance, Xavier Institute of Management working paper.

- La Rocca, La Rocca and Cariol (2007), «Overinvestment and Underinvestment Problems: Determining Factors, Consequences and Solutions» Corporate Ownership \& Control / Volume 5, Issue 1,pp79-95

- Lang L.H.P., Ofek O.and Stulz R.M. (1996), «Leverage, Investment, and Firm Growth », Journal of Financial Economics, vol. 40, p. 3-29.

- $\quad$ Li.K, H. Yue H and Zhao. L “Ownership, Institutions, and Capital Structure: Evidence from China," (2009), Journal of Comparative Economics 37, 471-490 


\section{Macrothink}

International Journal of Accounting and Financial Reporting ISSN 2162-3082 2013, Vol. 3, No. 2

- Lin, Huang and Young (2008), «An empirical study on the relationship between ownership and firm performance: Taiwan evidence »,Afro-Asian Journal of Finance and Accounting, Volume (1), Issue (1)

Pages: $67-80$

- Ljubojevic and Ljubojevic (2008), "Building Corporate Reputation through Corporate Governance ", University of Primorska, Faculty of Management Koper, Management, 3(3), pp:221-233

- Mehran, H., 1995. "Executive compensation structure, ownership, and firm performance," Journal of Financial Economics 38: 163-184.

- Mester, L.J., 1993. "Efficiency in the Savings and Loan Industry,” Journal of Banking and Finance 17: 267-86.

- Miller, Merton H. (1977), «Debt and Taxes, » Journal of Finance, 261-275.

- Myers, Stewart C (1977), «Determinants of Corporate Borrowing», Journal of Financial Economics, Vol. 5, n ${ }^{\circ}$ 2, November, pp. 147-175

- Nekhili M., Wali A. and Chebbi D, (2009), «Free cash flow, gouvernance et politique financière des entreprises françaises », Finance Contrôle Stratégie, Vol. 12, n 1, pp. $5-31$.

- Pao (2008), «A comparison of neural network and multiple regression analysis in modeling capital structure» Expert Systems with Applications 35, pp :720-727

- Pi, L., and S.G. Timme, 1993. "Corporate Control and Bank Efficiency," Journal of Banking and Finance 17:515-30.

- Pindado J., De la Torre C. (2005), «A Complementary Approach to the Financial and Strategy Views of Capital Structure: Theory and Evidence from the Ownership Structure », SSRN Working paper.

- Poulain-Rehm (2005), «L'impact de l'affectation du free cash flow sur la création de valeur actionnariale: le cas de la politique d'endettement et de dividendes des entreprises françaises cotées », Revue Finance, Contrôle, Stratégie, vol. 8, n4, décembre, p. 205-238.

- Rajan R.G, and L.Zingales (1995), «What do we know about capital structure? Some evidence from international data» Journal of Finance, vol 50, ${ }^{\circ}$ 5, pp. 1421-1460

- Sheikh and Wang (2010), «Financing Behavior of Textile Firms in Pakistan», International Journal of Innovation, Management and Technology, Vol. 1, No. 2, pp.130-135.

- Shyam-Sunder L., S.C Myers (1999), «Testing static tradeoff against pecking order models of capital structure», Journal of Financial Economics , 51 (1999) pp.219-244

- Solh, M., 2000, «Fonds de pension et politique d'investissement à long terme des 
entreprises», thèse de doctorat en sciences de gestion, Université de Paris X Nanterre

- Stulz, (1990), «Managerial Discretion and Optimal Financing Policies», Journal of Financial Economics, 26, 3-27

- Taggart, R.A., (1977), «A model of corporate financing decisions», Journal of Finance 32, pp. 1467-1484

- Titman and Wessels (1988), «The determinants of capital structure choice», Journal of Finance 43, pp. 1-19.

- Vilasuso, Jon and Minkler, Alanson, (2001), «Agency costs, asset specificity, and the capital structure of the firm», Journal of Economic Behavior \& Organization, vol. 44(1), pages 55-69, January

- Wiwattanakantang, Yupana, (1999), « An empirical study on the determinants of the capital structure of Thai firms ", Pacific-Basin Finance Journal, vol. 7(3-4), pages 371-403, August

- Wu and Yue (2009), «Corporate tax, capital structure, and the accessibility of bank loans: Evidence from China», Journal of Banking and Finance, Volume 33, Issue 1, pp.30-38

- Wu L. (2004), « The Impact of Ownership Structure on Debt Financing of Japanese Firms with the Agency Cost of Free cash flow », EFMA Meetings Paper.

- Zhang, H and Li, S, (2008), «The Impact of Capital Structure on Agency Costs: Evidence from UK Public Companies», Proceedings of the 16th Annual Conference on Pacific Basin Finance Economics Accounting Management (PBFEAM) Conference

- Zwiebel J., (1996), «Dynamic Capital Structure under Managerial Entrenchment», American Economic Review, vol. 86, n 5, p. 1197-1215. 